\title{
Preharvest seed infection by Aspergillus flavus group fungi and subsequent aflatoxin contamination in groundnuts in relation to soil types*
}

\author{
V.K. MEHAN ${ }^{1}$, C.D. MAYEE ${ }^{2}$, S. JAYANTHI ${ }^{1}$ and D. McDONALD ${ }^{1}$ \\ ${ }^{1}$ Legumes Program, International Crops Research Institute for the Semi-Arid Tropics (ICRISAT), \\ Patancheru, P.O. 502 324, A.P., India and ${ }^{2}$ Department of Plant Pathology, Marathwada \\ Agricultural University, Parbhani-431 402, India
}

Received 22 November 1990. Revised March 1991

Key words: Alfisols, Arachis hypogaea, Aspergillus flavus, A. parasiticus, seed infection, Vertisols

\begin{abstract}
Preharvest seed infection by Aspergillus flavus and aflatoxin contamination in selected groundnut genotypes (four $A$. flavus-resistant and four $A$. flavus-susceptible) were examined in different soil types at several locations in India in 1985-1990. Undamaged mature pods were sampled at harvest and seed examined for $A$. flavus infection and aflatoxin content in two or more trials at ICRISAT Center on light sandy soils and red sandy loam soils (Alfisols), and on Vertisols, at Anantapur on light sandy soils, and at Dharwad and Parbhani on Vertisols. Rainy season trials (1985-1989) were all rainfed. Post-rainy season trials were irrigated; late-season drought stress (90 days after sowing (DAS) until harvest at 125 DAS) was imposed in the $1987 / 88$ and $1989 / 90$ seasons. A. flavus infection and aflatoxin contamination levels were much lower in seed of all genotypes from Vertisols than in seed from Alfisols across locations and seasons. Vertisols also had significantly lower populations of $A$. flavus than Alfisols. There were no marked differences between light sandy soils and red sandy loam soils (Alfisols) in respect of seed infection by $A$. flavus and aflatoxin contamination. Significant interactions between genotypes and soil types were evident, especially in the $A$. flavus-susceptible genotypes. Irrespective of soil types, $A$. flavus-resistant genotypes showed lower levels of seed infection by $A$. flavus and other fungi than $\operatorname{did} A$. flavus-susceptible genotypes. The significance of the low preharvest aflatoxin risk in groundnuts grown on Vertisols is highlighted.
\end{abstract}

\section{Introduction}

Invasion of groundnut (Arachis hypogaea L.) pods and seeds by the aflatoxin-producing fungi Aspergillus flavus Link ex Fr. and $A$. parasiticus Speare, and subsequent contamination with aflatoxins, is a serious problem in most groundnutproducing countries (Dickens, 1977). In the wetter groundnut-producing areas, which usually have long rainy seasons, aflatoxin contamination

* ICRISAT Journal Article No. JA 1122 is mainly a postharvest problem. In the major groundnut-growing areas of the semi-arid tropics (SAT) the problem is largely of preharvest origin (Blaney, 1985; Manzo and Misari, 1989). Drought stress during late stages of pod development, a common occurrence in the SAT, predisposes seed to invasion by the aflatoxigenic fungi and consequently to aflatoxin contamination (Davidson et al., 1983; Sanders et al., 1985). Groundnuts are grown on a wide range of soils in the rainfed areas of the SAT, but very little attention has been given to possible lin- 
kages between soil type and aflatoxin contamination risk (Graham, 1982). The present studies were undertaken in the period 1985-1990 to examine preharvest seed infection by $A$. flavus and aflatoxin contamination in selected groundnut genotypes in three soil types at several locations in India.

\section{Materials and methods}

\section{Genotypes}

Eight groundnut genotypes, four with resistance to seed infection by A. flavus (Ah 7223, J 11, PI $337394 \mathrm{~F}$ and UF 71513) and four susceptible (TMV 2, JL 24, EC 76446(292) and NCAc 17090) (Mehan et al., 1987) were used in all trials. The genotypes Ah 7223, J 11, TMV 2 and JL 24 are spanish (A. hypogaea var. vulgaris) types and PI 337394F, UF 71513, EC 76446(292) and NCAc 17090 are valencia ( $A$. hypogaea var. fastigiata) types. They mature in 106-110 days in the rainy season and in 120-125 days in the post-rainy season at ICRISAT Center.

\section{Locations}

The trials were carried out in drought-prone locations in the Indian States of Andhra Pradesh (ICRISAT Center farm at Patancheru, and Anantapur), Karnataka (Dharwad), and Maharashtra (Parbhani). Trials at Dharwad and Parbhani locations were conducted in Vertisols, at ICRISAT Center in light sandy soils, red sandy loam soils and Vertisols, and at Anantapur in light sandy soils. Different fields were used at each location each season unless otherwise specified. Crop rotations followed at these locations were: millet-groundnut (groundnut in rainy season and millet in post-rainy season) at ICRISAT Center, sorghum-groundnut at Dharwad, and groundnut-groundnut (rainfed only, continuous groundnut cultivation in rainy season) at Parbhani and Anantapur. At ICRISAT Center, the light sandy (sandy loam) fields had $80 \%$ sand, $6 \%$ silt and $14 \%$ clay with an available water-holding capacity (AWHC) of 90$100 \mathrm{~mm}$, while the red sandy loam soil (sandy clay loam) fields had $73 \%$ sand, $8 \%$ silt and $18 \%$ clay with AWHC of 90-110 mm. Vertisols (silty clay loam) had $36 \%$ sand, $14 \%$ silt and $50 \%$ clay, with a high AWHC of $180-200 \mathrm{~mm}$. At Anantapur, the light sandy soil fields had AWHC of about $50 \mathrm{~mm}$. Vertisols at Dharwad and Parbhani had a AWHC of $150-160 \mathrm{~mm}$. The $\mathrm{pH}$ of Alfisols (light sandy and red sandy loam soils) ranged from 6.8 to 7.3 and of Vertisols from 8.3-8.5. Normal cultural practices were followed and card was taken to harvest each genotype at optimum maturity and to sample only undamaged mature pods. No fungicides or insecticides were used.

Data on rainfall, and maximum and minimum temperatures during the crop seasons were obtained from ICRISAT, Anantapur, Dharwad and Parbhani Meteorological Stations.

\section{Rainy-season trials (1985-1989)}

All rainy-season trials were rainfed, sowing dates being normal (June-July) for the locations. In the 1985 and 1986 rainy seasons, research was done only at ICRISAT Center, trials being conducted on light sandy soil fields, on red sandy loam soil fields (Alfisols), and on Vertisol fields.

In the 1987 and 1988 rainy seasons, trials were carried out on light sandy soils, red sandy loam soils, and Vertisols at ICRISAT Center, on light sandy soils at Anantapur, and on Vertisols at Dharwad and Parbhani. The trials were repeated in the 1989 rainy season at all locations, except Dharwad.

All trials were carried out in randomized block design with four replications. Groundnuts were grown in 9-m-long plots of 10 rows $30 \mathrm{~cm}$ apart with seeds sown singly at $10-\mathrm{cm}$ spacing along the rows.

\section{Post-rainy season trials}

The trials were conducted at ICRISAT Center in the $1987 / 88$ post-rainy season and at ICRISAT Center and Parbhani in the $1989 / 90$ post-rainy season; on red sandy loam soils and Vertisols at ICRISAT Center, and on Vertisols at Parbhani. All trials were carried out in randomized block design with four replications. The post-rainy season crops were grown on raised ridges. Plots were $9 \mathrm{~m}$ long and $7.5 \mathrm{~m}$ wide. Seeds were sown 
singly at $10-\mathrm{cm}$ spacing along $75-\mathrm{cm}$-wide ridges. All plots were furrow-irrigated to field capacity (at 10-day intervals) until 90 days after sowing (DAS). Drought stress was then imposed from 90 DAS until harvest (125 DAS) by withholding irrigation.

\section{Collection and preparation of pod samples}

Genotypes were harvested at maturity. At harvest, 35-40 plants were selected at random from each plot, and about 500 mature undamaged pods were collected from them.

At ICRISAT Center, the pods were immediately shelled, and seeds from each plot were examined for infection by $A$. flavus group fungi and other fungi and for aflatoxin contamination.

At the other locations, the pods were sundried in windrows for 2 days and then transported within a day to ICRISAT Center where they were shelled and seed samples taken for fungal and aflatoxin analyses.

\section{Seed testing for fungal infection}

Two hundred seeds from each plot were examined for infection by $A$. flavus and other fungi using standard techniques (Mehan et al., 1986). No distinction was made between the colonies of $A$. flavus and $A$. parasiticus Speare, both being referred to as $A$. flavus group fungi in this paper.

\section{Seed testing for aflatoxin contamination}

Two 50-g samples of seed from each plot were tested for aflatoxin content by the method of Pons et al. (1966).

Estimation of soil populations of A. flavus group fungi

Soil populations of $A$. flavus group fungi were monitored in selected trials at ICRISAT Center at different stages of crop development. In the 1987 and 1989 rainy seasons, they were monitored at sowing, $60 \mathrm{DAS}$, and $105 \mathrm{DAS}$. In the $1987 / 88$ and $1989 / 90$ post-rainy season trials, they were monitored at sowing, 60 DAS, 90 DAS, and 105 DAS. In the $1989 / 90$ post-rainy season, soil populations of $A$. flavus group fungi were also monitored in 4 additional groundnut fields each in Alfisols and Vertisols. At each sampling time, soil samples were collected from five randomly selected spots at $0-10 \mathrm{~cm}$ depth from between plants (field soil), individual samples were pooled for each plot. All soil samples were taken to the laboratory in polyethylene bags within $2 \mathrm{~h}$ of collection. After thorough mixing, from each composite sample, three subsamples ( $4 \mathrm{~g}$ each) were taken for tests. The dilution plate technique was used to obtain soil populations of $A$. flavus group fungi. Each subsample was put into $100 \mathrm{~mL}$ of sterile, distilled water in $250-\mathrm{mL}$ flasks. One $\mathrm{mL}$ of the selected soil suspension $\left(10^{1}\right.$ or $10^{2}$ dilution) was poured onto malt salt agar medium (Griffin and Garren, 1976) in 9-cm diameter petri plates, three plates per sample. The plates were then incubated at $25^{\circ} \mathrm{C}$ in the dark. Colonies of $A$. flavus group fungi growing onto the medium in each plate were counted 6-7 days after incubation and averages calculated for each sample. Each colony was considered to have originated from a single fungal propagule.

\section{Statistical analysis}

The mean seed infection levels and aflatoxin contents were estimated with standard errors using analyses of variance performed separately on data from each season over Alfisols (red sandy loam and light sandy loam soils), and over Vertisols. Genotype $\times$ soil type interactions were computed separately for $A$. flavus-resistant and -susceptible genotypes. Analyses of variance were also carried out for seed infection by $A$. flavus, and for aflatoxin $\mathrm{B}_{1}$ content, over the soil types separately for $A$. flavus-resistant and -susceptible genotypes. Analyses of variance were also done for soil populations of $A$. flavus across sampling times.

\section{Results}

Natural seed infection by $A$. flavus and aflatoxin levels of test genotypes grown in different soils at ICRISAT Center for the 1985 and 1986 rainy seasons are given in Table 1. Significant differences occurred between soils for seed infection 
Table 1. Seed infection by Aspergillus flavus group fungi and aflatoxin contamination in groundnut genotypes grown in different soils at ICRISAT Center, 1985 and 1986 rainy seasons

\begin{tabular}{|c|c|c|c|c|c|c|}
\hline \multirow[t]{4}{*}{ Genotype } & \multicolumn{6}{|c|}{ Percentage of seed infected by $A$. flavus group fungi, and aflatoxin contamination } \\
\hline & \multicolumn{3}{|l|}{1985} & \multicolumn{3}{|l|}{1986} \\
\hline & \multicolumn{2}{|l|}{ Alfisols } & \multirow[t]{2}{*}{ Vertisols } & \multicolumn{2}{|l|}{ Alfisols } & \multirow[t]{2}{*}{ Vertisols } \\
\hline & $\begin{array}{l}\text { Red sandy } \\
\text { loam soil }\end{array}$ & $\begin{array}{l}\text { Light } \\
\text { sandy } \\
\text { soil }\end{array}$ & & $\begin{array}{l}\text { Red sandy } \\
\text { loam soil }\end{array}$ & $\begin{array}{l}\text { Light } \\
\text { sandy } \\
\text { soil }\end{array}$ & \\
\hline Ah 7223 & $\begin{array}{c}1.9^{\mathrm{a}} \\
(2.8)^{\mathrm{b}}\end{array}$ & $\begin{array}{c}1.4 \\
(3.0)\end{array}$ & $\begin{array}{c}0.1 \\
(0.0)\end{array}$ & $\begin{array}{c}0.9 \\
(2.5)\end{array}$ & $\begin{array}{c}1.1 \\
(6.1)\end{array}$ & $\begin{array}{c}0.0 \\
(0.0)\end{array}$ \\
\hline $\mathrm{J} 11$ & $\begin{array}{c}2.0 \\
(1.6)\end{array}$ & $\begin{array}{c}1.1 \\
(2.5)\end{array}$ & $\begin{array}{c}0.1 \\
(0.0)\end{array}$ & $\begin{array}{c}1.2 \\
(1.0)\end{array}$ & $\begin{array}{c}1.2 \\
(7.6)\end{array}$ & $\begin{array}{c}0.0 \\
(0.0)\end{array}$ \\
\hline UF 71513 & $\begin{array}{c}2.0 \\
(2.2)\end{array}$ & $\begin{array}{c}1.4 \\
(4.5)\end{array}$ & $\begin{array}{c}0.2 \\
(0.0)\end{array}$ & $\begin{array}{c}1.1 \\
(5.7)\end{array}$ & $\begin{array}{c}1.6 \\
(8.7)\end{array}$ & $\begin{array}{c}0.0 \\
(0.0)\end{array}$ \\
\hline PI 337394F & $\begin{array}{c}2.1 \\
(4.6)\end{array}$ & $\begin{array}{c}1.6 \\
(8.9)\end{array}$ & $\begin{array}{c}0.2 \\
(0.0)\end{array}$ & $\begin{array}{c}1.6 \\
(7.4)\end{array}$ & $\begin{array}{c}2.1 \\
(11.1)\end{array}$ & $\begin{array}{c}0.0 \\
(0.0)\end{array}$ \\
\hline SE & \multicolumn{2}{|c|}{$\begin{array}{r} \pm 0.18^{\mathrm{c}} \\
( \pm 0.49)\end{array}$} & $\pm 0.07^{\mathrm{d}}$ & \multicolumn{2}{|c|}{$\begin{array}{r} \pm 0.16^{\circ} \\
( \pm 2.61)\end{array}$} & \\
\hline TMV 2 & $\begin{array}{c}5.0 \\
(25.7)\end{array}$ & $\begin{array}{c}4.5 \\
(34.8)\end{array}$ & $\begin{array}{c}2.0 \\
(0.5)\end{array}$ & $\begin{array}{c}6.1 \\
(26.7)\end{array}$ & $\begin{array}{c}7.2 \\
(60.0)\end{array}$ & $\begin{array}{c}0.6 \\
(0.0)\end{array}$ \\
\hline JL 24 & $-^{e}$ & - & - & $\begin{array}{c}12.2 \\
(80.5)\end{array}$ & $\begin{array}{c}18.5 \\
(89.0)\end{array}$ & $\begin{array}{c}1.4 \\
(0.0)\end{array}$ \\
\hline NCAc 17090 & $\begin{array}{c}17.2 \\
(12.7)\end{array}$ & $\begin{array}{c}17.7 \\
(20.7)\end{array}$ & $\begin{array}{c}2.7 \\
(0.0)\end{array}$ & $\begin{array}{c}27.0 \\
(81.8)\end{array}$ & $\begin{array}{c}20.9 \\
(76.0)\end{array}$ & $\begin{array}{c}2.0 \\
(0.0)\end{array}$ \\
\hline $\begin{array}{l}\text { EC } 76446 \\
(292)\end{array}$ & $\begin{array}{c}15.5 \\
(20.2)\end{array}$ & $\begin{array}{c}17.1 \\
(40.8)\end{array}$ & $\begin{array}{c}3.5 \\
(0.0)\end{array}$ & $\begin{array}{c}23.4 \\
(236.3)\end{array}$ & $\begin{array}{c}21.3 \\
(139.0)\end{array}$ & $\begin{array}{c}2.1 \\
(0.0)\end{array}$ \\
\hline SE & & & $\begin{array}{c} \pm 0.45^{\mathrm{d}} \\
( \pm 0.29)\end{array}$ & & & $\pm 0.16^{d}$ \\
\hline
\end{tabular}

${ }^{a}$ Seed infected by A. flavus (\%).

${ }^{\mathrm{b}}$ Aflatoxin $\mathrm{B}_{1}$ content (ug kg ${ }^{-1}$ ).

${ }^{c}$ SEs apply to non-zero mean values. SEs are for comparing both red sandy loam and light sandy soils as well as genotypes.

${ }^{d}$ SEs apply to non-zero mean values. SEs are for comparing genotypes in Vertisols.

e Not tested.

and aflatoxin levels at time of harvest; levels being much lower in Vertisols than in Alfisols. However, the two groups of Alfisols light sandy soils and red sandy loam soils did not differ significantly in these respects. No significant differences were observed between genotypes in the $A$. flavus-resistant group for infection and aflatoxin levels, but there were highly significant differences between genotypes in the A. flavussusceptible group in these respects in both years. Significant interactions also occurred between soil types and genotypes, particularly in the susceptible group.

Significant differences between soils were also noted for $A$. flavus infection and aflatoxin con- tamination of seed in the 1987 rainy season trials conducted at ICRISAT Center and three other locations, viz. Anantapur, Dharwad and Parbhani (Table 2). Levels of seed infection and aflatoxin $B_{1}$ contamination were lower in Vertisols than in Alfisols at all locations. Significant differences also occurred between Alfisols; levels of seed infection and aflatoxin contamination were higher in most susceptible genotypes in light sandy soils than in red sandy loam soils. Significant interactions were observed between soil types and genotypes in the A. flavus-susceptible group of genotypes.

In the 1988 rainy season trials, the levels of infection in the susceptible genotypes were too 
Table 2. Seed infection by Aspergillus flavus group fungi and aflatoxin contamination in groundnut genotypes grown in different soils at various locations, rainy season 1987

\begin{tabular}{|c|c|c|c|c|c|c|}
\hline \multirow[t]{4}{*}{ Genotype } & \multicolumn{6}{|c|}{ Percentage of seed infected by $A$. flavus group fungi, and aflatoxin contamination } \\
\hline & \multicolumn{3}{|l|}{ Alfisols } & \multicolumn{3}{|l|}{ Vertisols } \\
\hline & \multicolumn{2}{|c|}{ ICRISAT Center } & \multirow{2}{*}{$\begin{array}{l}\text { Anantapur } \\
\text { Light sandy } \\
\text { soil }\end{array}$} & ICRISAT Center & \multirow[t]{2}{*}{ Parbhani } & \multirow[t]{2}{*}{ Dharwad } \\
\hline & $\begin{array}{l}\text { Light sandy } \\
\text { soil }\end{array}$ & $\begin{array}{l}\text { Red sandy } \\
\text { loam soil }\end{array}$ & & & & \\
\hline Ah 7223 & $\begin{array}{c}0.9^{\mathrm{a}} \\
(0.0)^{\mathrm{b}}\end{array}$ & $\begin{array}{c}0.9 \\
(0.5)\end{array}$ & $\begin{array}{c}0.5 \\
(0.0)\end{array}$ & $\begin{array}{c}0.1 \\
(0.0)\end{array}$ & $\begin{array}{c}0.1 \\
(0.0)\end{array}$ & $\begin{array}{c}0.0 \\
(0.0)\end{array}$ \\
\hline J 11 & $\begin{array}{c}1.0 \\
(0.5)\end{array}$ & $\begin{array}{c}1.0 \\
(0.0)\end{array}$ & $\begin{array}{c}0.7 \\
(0.0)\end{array}$ & $\begin{array}{c}0.0 \\
(0.0)\end{array}$ & $\begin{array}{c}0.0 \\
(0.0)\end{array}$ & $\begin{array}{c}0.0 \\
(0.0)\end{array}$ \\
\hline UF 71513 & $\begin{array}{c}1.0 \\
(0.0)\end{array}$ & $\begin{array}{c}0.9 \\
(0.5)\end{array}$ & $\begin{array}{c}0.7 \\
(1.0)\end{array}$ & $\begin{array}{c}0.1 \\
(0.0)\end{array}$ & $\begin{array}{c}0.0 \\
(0.0)\end{array}$ & $\begin{array}{c}0.0 \\
(0.0)\end{array}$ \\
\hline PI 337394F & $\begin{array}{c}1.2 \\
(0.0)\end{array}$ & $\begin{array}{c}1.4 \\
(0.0)\end{array}$ & $\begin{array}{c}0.6 \\
(0.0)\end{array}$ & $\begin{array}{c}0.0 \\
(0.0)\end{array}$ & $\begin{array}{c}0.0 \\
(0.0)\end{array}$ & $\begin{array}{c}0.1 \\
(0.0)\end{array}$ \\
\hline SE & \multicolumn{2}{|c|}{$\begin{array}{c} \pm 0.11^{\mathrm{c}} \\
( \pm 0.23)\end{array}$} & \multicolumn{4}{|c|}{ $\pm 0.04^{\mathrm{d}}$} \\
\hline TMV 2 & $\begin{array}{c}4.7 \\
(1.0)\end{array}$ & $\begin{array}{c}4.9 \\
(2.9)\end{array}$ & $\begin{array}{c}3.4 \\
(0.5)\end{array}$ & $\begin{array}{c}0.4 \\
(0.0)\end{array}$ & $\begin{array}{c}0.1 \\
(0.0)\end{array}$ & $\begin{array}{c}0.4 \\
(1.0)\end{array}$ \\
\hline $\mathrm{JL} 24$ & $\begin{array}{l}11.9 \\
(2.9)\end{array}$ & $\begin{array}{c}12.9 \\
(10.5)\end{array}$ & $\begin{array}{c}9.2 \\
(0.0)\end{array}$ & $\begin{array}{c}1.1 \\
(0.0)\end{array}$ & $\begin{array}{c}0.4 \\
(0.0)\end{array}$ & $\begin{array}{c}1.0 \\
(0.5)\end{array}$ \\
\hline NCAc 17090 & $\begin{array}{l}17.2 \\
(2.5)\end{array}$ & $\begin{array}{l}14.6 \\
(8.4)\end{array}$ & $\begin{array}{c}9.9 \\
(1.0)\end{array}$ & $\begin{array}{c}1.2 \\
(0.0)\end{array}$ & $\begin{array}{c}0.5 \\
(0.8)\end{array}$ & $\begin{array}{c}1.2 \\
(0.0)\end{array}$ \\
\hline $\begin{array}{l}\text { EC 76446 } \\
(292)\end{array}$ & $\begin{array}{c}21.4 \\
(12.2)\end{array}$ & $\begin{array}{c}17.2 \\
(13.4)\end{array}$ & $\begin{array}{l}10.6 \\
(4.0)\end{array}$ & $\begin{array}{c}1.5 \\
(0.0)\end{array}$ & $\begin{array}{c}0.6 \\
(0.0)\end{array}$ & $\begin{array}{c}1.1 \\
(0.5)\end{array}$ \\
\hline SE & \multicolumn{2}{|c|}{$\begin{array}{c} \pm 1.08^{\circ} \\
( \pm 1.52)\end{array}$} & \multicolumn{4}{|c|}{$\begin{array}{r} \pm 0.14^{d} \\
( \pm 0.26) \\
\end{array}$} \\
\hline
\end{tabular}

"Seed infected by A. flavus (\%).

"Aflatoxin $\mathrm{B}_{1}$ content $\left(\mu \mathrm{g} \mathrm{kg}^{-1}\right)$.

"SEs apply to non-zero mean values. SEs are for comparing both light sandy and red sandy loam soils as well as genotypes.

"SEs apply to non-zero mean values. SEs are for comparing both Vertisols (ICRISAT Center, Parbhani and Dharwad) as well as genotypes.

low $(<2 \%$ ) to provide meaningful comparisons and so no data are given in Table 2 for these trials.

In the 1989 rainy season, significant differences were again noted between soil types for $A$. flavus infection of seeds (Table 3 ). Levels of infection were significantly higher in seed from Alfisols than in seeds from Vertisols. There were significant interactions between soil types and genotypes, especially for the $A$. flavus-susceptible genotypes, for seed infection by $A$. flavus. Aflatoxin $B_{1}$ contamination was observed only in some seed samples of the genotypes NCAc 17090 (10-12 $\left.\mu \mathrm{g} \mathrm{kg}^{-1}\right)$ and EC 76446(292) (8-16 $\mu \mathrm{g}$ $\mathrm{kg}^{-1}$ ) grown in Alfisols at ICRISAT Center and Anantapur.

The trials were also conducted under imposed late-season drought stress at ICRISAT Center in the $1987 / 88$ post-rainy season and at ICRISAT Center and Parbhani in the $1989 / 90$ post-rainy season. Levels of seed infection by $A$. flavus are presented in Table 4. Significant differences were observed between soil types for $A$. flavus infection levels in both seasons, levels of infection being significantly higher in seed from Alfisols than in seed from Vertisols. Significant genotype $\times$ soil type interactions were evident in the A. flavus-susceptible group. Only low levels of 
Table 3. Seed infection by Aspergillus flavus group fungi in groundnut genotypes grown in different soils at various locations, rainy season 1989

\begin{tabular}{|c|c|c|c|c|c|}
\hline \multirow[t]{4}{*}{ Genotype } & \multicolumn{5}{|c|}{ Percentage of seed infected by $A$. flavus group fungi } \\
\hline & \multicolumn{3}{|l|}{ Alfisols } & \multicolumn{2}{|l|}{ Vertisols } \\
\hline & \multicolumn{2}{|c|}{ ICRISAT Center } & \multirow{2}{*}{$\begin{array}{l}\text { Anantapur } \\
\text { Light sandy } \\
\text { soil }\end{array}$} & \multirow[t]{2}{*}{ ICRISAT Center } & \multirow[t]{2}{*}{ Parbhan } \\
\hline & $\begin{array}{l}\text { Light sandy } \\
\text { soil }\end{array}$ & $\begin{array}{l}\text { Red sandy } \\
\text { loam soil }\end{array}$ & & & \\
\hline Ah 7223 & $0.1^{4}$ & 0.1 & 0.0 & 0.0 & 0.0 \\
\hline J 11 & 0.1 & 0.0 & 0.0 & 0.0 & 0.0 \\
\hline UF 71513 & 0.1 & 0.1 & 0.2 & 0.0 & 0.0 \\
\hline PI 337394F & 0.1 & 0.0 & 0.2 & 0.0 & 0.0 \\
\hline SE & & $\pm 0.13^{\mathrm{h}}$ & & & \\
\hline TMV 2 & 1.2 & 1.0 & 0.7 & 0.2 & 0.0 \\
\hline JL 24 & 1.2 & 2.1 & 3.2 & 0.5 & 0.2 \\
\hline NCAc 17090 & 2.7 & 5.1 & 3.5 & 0.2 & 0.0 \\
\hline EC 76446(292) & 3.5 & 11.2 & 4.7 & 0.0 & 0.5 \\
\hline SE & & $\pm 0.46^{\mathrm{h}}$ & & \pm 0.25 & \\
\hline
\end{tabular}

${ }^{a}$ Seed infected by $A$. flavus (\%).

'SEs apply to non-zero mean values. SEs are for comparing both light sandy and red sandy loam soils as well as genotypes.

${ }^{c}$ SEs apply to non-zero mean values. SEs are for comparing both Vertisols (ICRISAT Center and Parbhani) as well as genotypes.

aflatoxin $\mathrm{B}_{1}\left(2-8 \mu \mathrm{g} \mathrm{kg}^{-1}\right)$ were detected in seed samples of some susceptible cultivars, viz. EC 76446(292), NCAc 17090, and JL 24 from Alfisols. No aflatoxin contamination was evident in seed of any genotype from the Vertisols.

There were significant differences between soil types for $A$. flavus group fungi populations in the
1987 and 1989 rainy seasons and the $1987 / 88$ and 1989/90 post-rainy seasons (Figs. 1 and 2). Significantly lower populations were recorded in Vertisols than in Alfisols across seasons. Populations of $A$. flavus tended to increase with time in Alfisols, but considerable fluctuations in population were observed.

Table 4. Seed infection by Aspergillus flavus group fungi in groundnut genotypes grown in different soils at ICRISAT Center and Parbhani, $1987 / 88$ and $1989 / 90$ postrainy seasons

\begin{tabular}{|c|c|c|c|c|c|}
\hline \multirow[t]{5}{*}{ Genotype } & \multicolumn{5}{|c|}{ Seed infected by $A$. flavus group fungi ( $\%$ ) } \\
\hline & \multicolumn{2}{|l|}{$1987 / 88$} & \multicolumn{3}{|l|}{$1989 / 90$} \\
\hline & \multicolumn{2}{|c|}{ ICRISAT Center } & \multicolumn{2}{|c|}{ ICRISAT Center } & \multirow{2}{*}{$\frac{\text { Parbhani }}{\text { Vertisol }}$} \\
\hline & Alfisol & Vertisol & Alfisol & Vertisol & \\
\hline & $\begin{array}{l}\text { Red sandy } \\
\text { loam soil }\end{array}$ & & $\begin{array}{l}\text { Red sandy } \\
\text { loam soil }\end{array}$ & & \\
\hline Ah 7223 & 0.0 & 0.0 & 1.2 & 0.2 & 0.1 \\
\hline J 11 & 0.5 & 0.0 & 0.6 & 0.1 & 0.1 \\
\hline UF 71513 & 0.0 & 0.2 & 1.0 & 0.2 & 0.2 \\
\hline PI 337394F & 0.0 & 0.0 & 1.2 & 0.6 & 0.2 \\
\hline $\mathrm{SE}$ & $\pm 0.00^{\mathrm{a}}$ & $\pm 0.08^{a}$ & $\pm 0.19^{\mathrm{a}}$ & & \\
\hline TMV 2 & 4.2 & 0.2 & 5.2 & 1.1 & 0.2 \\
\hline JL 24 & 7.5 & 0.0 & 9.9 & 1.7 & 1.5 \\
\hline NCAc 17090 & 6.8 & 0.3 & 12.5 & 2.1 & 1.0 \\
\hline EC 76446(292) & 8.8 & 0.7 & 13.9 & 2.1 & 1.2 \\
\hline SE & $\pm 0.91^{\mathrm{a}}$ & $\pm 0.13^{\mathrm{a}}$ & $\pm 0.66^{\mathrm{a}}$ & & \\
\hline
\end{tabular}

${ }^{a}$ SEs apply to non-zero mean values. SEs are for comparing genotypes.

${ }^{\mathrm{b}}$ SEs apply to non-zero mean values. SEs are for comparing both Vertisols (ICRISAT Center and Parbhani) as well as genotypes. 
Llont sandy soll

Vertisols

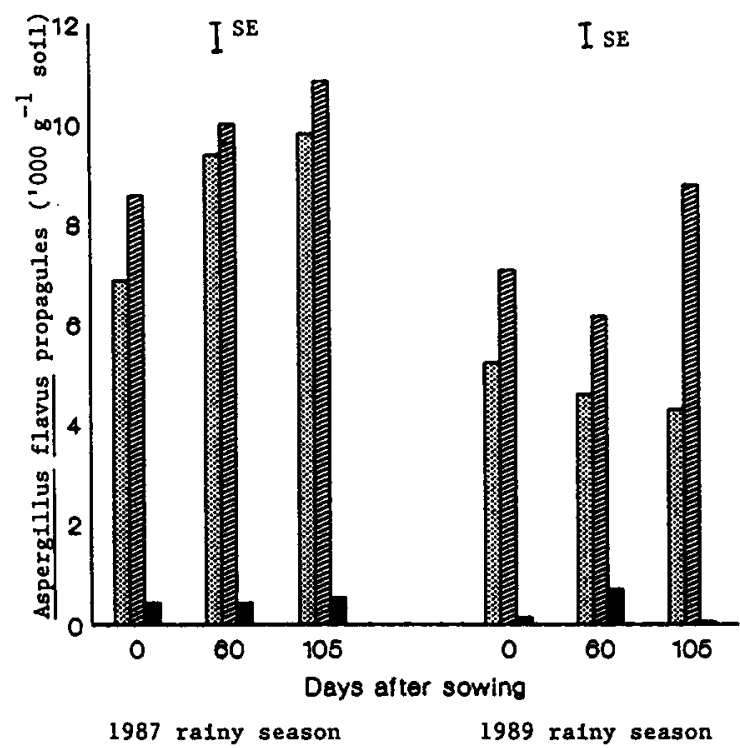

Fig. 1. Soil populations of Aspergillus flavus in light sandy soils and red sandy loam soils (Alfisols) and Vertisols during the 1987 and 1989 rainy seasons at ICRISAT Center.

Significant differences for soil populations of A. flavus between soil types were also noted when additional Alfisol and Vertisol groundnut fields were examined in the $1989 / 90$ post-rainy season. Populations of the fungus were much lower in Vertisol fields $(218$ to 340 propagules $\mathrm{g}^{-1}$ soil) than in Alfisol fields (4271 to 7219 propagules $\mathrm{g}^{-1}$ soil) (Fig. 3).

There were also significant differences between soil types for seed infection by fungi other than A. flavus. Aspergillus niger van Tieghem, Macrophomina phaseolina (Tassi.) Goid., and Penicillium spp. were dominant in seed from Vertisols in all seasons in most locations. Fusarium spp., and $A$. niger were commonly isolated from seed from Alfisols in both rainy and post-rainy seasons, and $M$. phaseolina was important particularly in the post-rainy seasons. No Penicillium spp. were recorded in seed from soils at Dharwad. M. phaseolina was predominant at Parbhani. Genotypes resistant to A. flavus had low percentages (0.9-6.2\% in Alfisols; 0.9$13.8 \%$ in Vertisols) of seed infected by these fungi in all seasons across locations, while susceptible genotypes had substantial infection (5.5-53.2\% in Alfisols; $3.5-52.0 \%$ in Vertisols). Among the susceptible genotypes, EC 76446(292), NCAc 17090 and JL 24 had significantly high levels of infection by $A$. niger and Penicillium spp. Significant interactions occurred between genotypes and soil types, particularly in

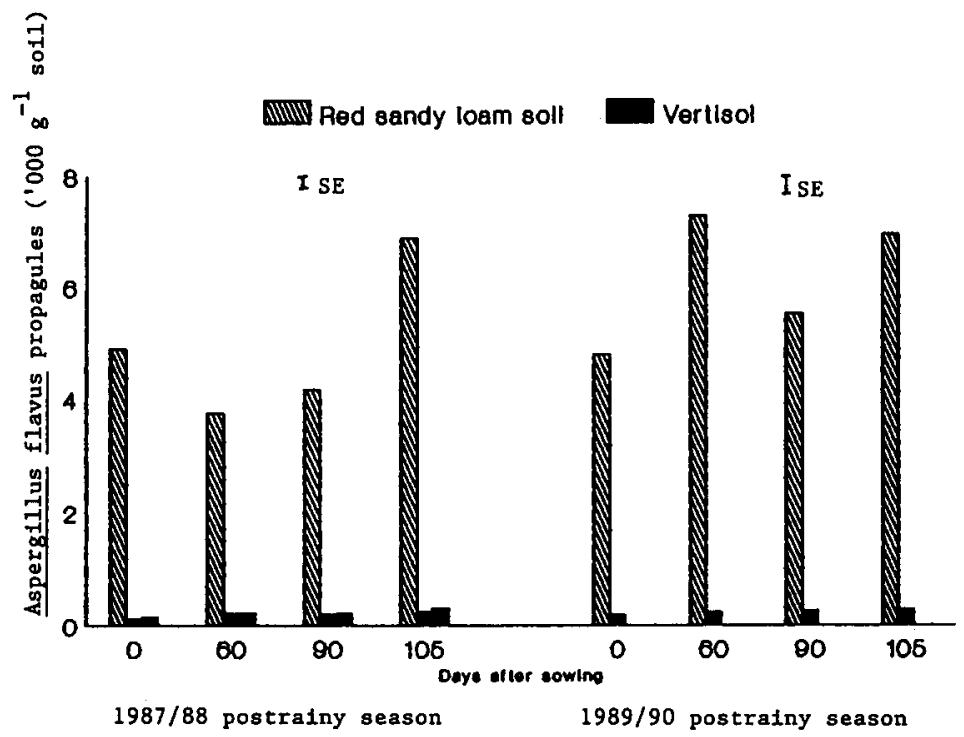

Fig. 2. Soil populations of Aspergillus flavus in red sandy loam soils (Alfisols) and Vertisols during the 1987/88 and 1989/90 post-rainy seasons at ICRISAT Center. 


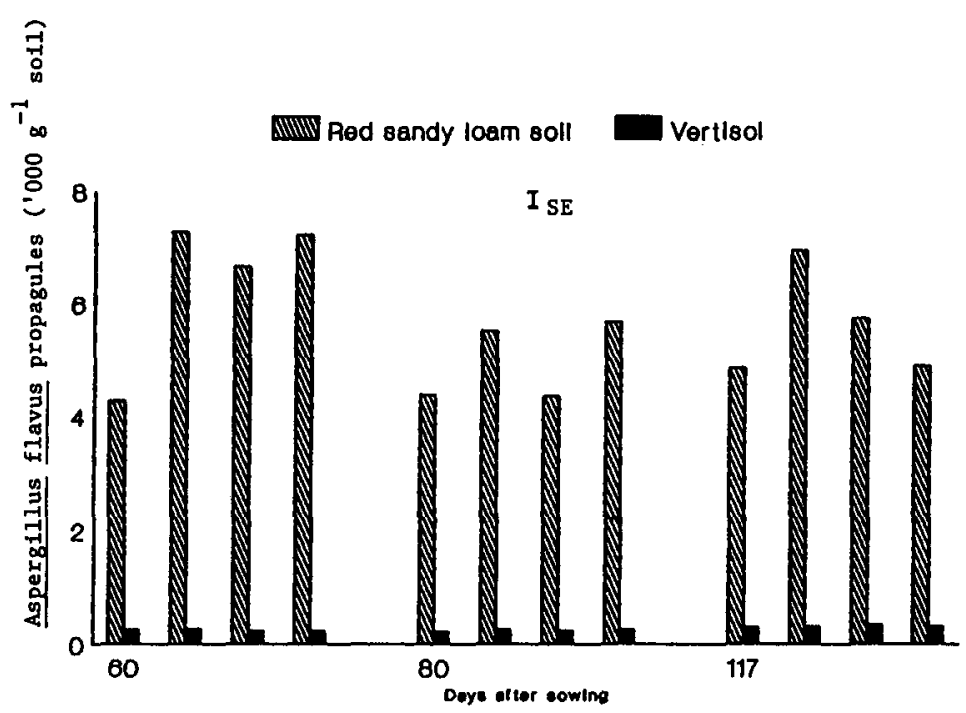

Fig. 3. Soil populations of Aspergillus flavus in four red sandy loam soil fields (Alfisols) and four Vertisol fields during the 1989/90 post-rainy season at ICRISAT Center.

the susceptible group genotypes, in respect of overall fungal infection.

Rainfall received by the groundnut crops grown in different soils in the various locations during the rainy seasons of 1985-1989 is shown in Table 5. There was considerable variation in rainfall between locations and seasons. In most situations, conditions were conducive to seed infection by the aflatoxin-producing fungi and for aflatoxin contamination as moderate to severe drought stress occurred during pod maturation.

\section{Discussion}

The present investigations have clearly shown that $A$. flavus infection and aflatoxin levels were much lower in seed of all genotypes from Vertisols than in seed from Alfisols (light sandy and red sandy loam soils) across locations in all seasons. Graham (1982) reported similar observations from limited trials in Queensland, $\mathrm{Au}$ stralia. It is pertinent to raise the important question whether these differences in infection and aflatoxin contamination were due to soil types or other environmental factors. Differences between the soil types in such factors as aeration, water-holding capacity, and $\mathrm{pH}$ can be important, and these reflect soil type as well as weather effects. This could primarily be related to water-holding capacities of the soils; Vertisols have high water-holding capacities (150-180 $\mathrm{mm}$ ) and groundnuts grown on these soils may be less prone to severe drought stress favorable for $A$. flavus infection and consequent aflatoxin contamination of groundnuts than those grown on Alfisols that have lower water-holding capacities (90-100 mm). Indeed, only low levels of seed infection by $A$. flavus and aflatoxin contamination occurred in Vertisols even when rainfall was very scanty during pod development and maturation stages of crop development in the 1986, 1987 and 1989 rainy seasons (Table 5).

Late-season drought stress is known to favor A. flavus infection and aflatoxin contamination (Pettit et al., 1971; Sanders et al., 1981). Low levels of $A$. flavus infection in Vertisols were also confirmed in trials over the post-rainy seasons, and it is important that the low levels were maintained under imposed late-season drought stress. Alfisols appear to favor rapid proliferation of $A$. flavus and seed infection, particularly under dry conditions late in the growing season. This is evident from the much higher soil populations of the fungus found in Alfisols than in Vertisols, fluctuations in the populations being influenced by rainfall patterns. Soil populations of $A$. flavus were low in several groundnut fields 
Table 5. Rainfall received by groundnut crops grown in different soils at various locations, rainy seasons 1985-1989

\begin{tabular}{|c|c|c|c|c|c|c|c|}
\hline \multirow[t]{3}{*}{ Year } & \multirow[t]{3}{*}{$\begin{array}{l}\text { Soil type/ } \\
\text { location }\end{array}$} & \multirow[t]{3}{*}{$\begin{array}{l}\text { Sowing } \\
\text { date }\end{array}$} & \multirow{3}{*}{$\begin{array}{l}\text { Total } \\
\text { rainfall } \\
\text { received } \\
(\mathrm{mm})\end{array}$} & \multicolumn{4}{|c|}{$\begin{array}{l}\text { Rain (in } \mathrm{mm} \text { ) received by the crops } \\
\text { at different stages of crop maturity }\end{array}$} \\
\hline & & & & \multicolumn{4}{|c|}{ Days after sowing } \\
\hline & & & & $1-30$ & $31-60$ & $61-90$ & $91-110$ \\
\hline \multirow[t]{4}{*}{1985} & Alfisol $^{\mathrm{a}}$ & & & & & & \\
\hline & ICRISAT Center & 24.6 .85 & 403.3 & 121.7 & 101.2 & 93.0 & 87.4 \\
\hline & Vertisol & & & & & & \\
\hline & ICRISAT Center & 26.6 .85 & 401.5 & 115.9 & 97.2 & 91.0 & 97.4 \\
\hline \multirow[t]{4}{*}{1986} & Alfisol & & & & & & \\
\hline & ICRISAT Center & 17.6 .86 & 461.9 & 69.6 & 312.3 & 76.3 & 3.7 \\
\hline & Vertisol & & & & & & \\
\hline & ICRISAT Center & 18.6 .86 & 461.6 & 99.7 & 281.9 & 76.3 & 3.7 \\
\hline \multirow[t]{7}{*}{1987} & Alfisol & & & & & & \\
\hline & ICRISAT Center & 17.6 .87 & 454.9 & 249.0 & 69.2 & 95.5 & 41.2 \\
\hline & Anantapur ${ }^{b}$ & 1.7 .87 & 280.1 & 9.8 & 90.1 & 120.4 & 59.8 \\
\hline & Vertisol & & & & & & \\
\hline & ICRISAT Center & 17.6 .87 & 454.9 & 249.0 & 69.2 & 95.9 & 41.2 \\
\hline & Dharwad & 9.7 .87 & 362.0 & 45.6 & 47.3 & 174.1 & 95.0 \\
\hline & Parbhani & 26.7 .87 & 491.6 & 330.0 & 34.0 & 123.6 & 4.0 \\
\hline \multirow[t]{6}{*}{1988} & Alfisol & & & & & & \\
\hline & ICRISAT Center & 17.6 .88 & 886.4 & 198.8 & 234.3 & 312.9 & 140.4 \\
\hline & & 20.6 .88 & 818.2 & 175.7 & 283.7 & 243.5 & 115.3 \\
\hline & Anantapur & 13.7 .88 & 656.5 & 97.5 & 420.3 & 138.8 & 0.0 \\
\hline & Vertisol & & & & & & \\
\hline & ICRISAT Center & 20.6 .88 & 816.1 & 175.3 & 285.4 & 247.1 & 108.3 \\
\hline \multirow[t]{6}{*}{1989} & Alfisol & & & & & & \\
\hline & ICRISAT Center & 30.6 .89 & 838.0 & 415.7 & 91.7 & 286.0 & 44.6 \\
\hline & Anantapur & 10.7 .89 & 569.7 & 191.2 & 133.9 & 208.1 & 36.5 \\
\hline & Vertisol & & & & & & \\
\hline & ICRISAT Center & 1.7 .89 & 838.0 & 415.7 & 91.7 & 288.4 & 42.2 \\
\hline & Parbhani & 20.7 .89 & 894.1 & 491.5 & 335.2 & 67.4 & 0.0 \\
\hline
\end{tabular}

"At ICRISAT Center Alfisol included a light sandy soil field and a sandy loam soil field each season; date of sowing was same for these soil types

${ }^{b}$ At Anantapur Alfisol included only red sandy loam soil fields.

in Vertisols at ICRISAT Center. Similar observations were recorded at Parbhani in the 1989/90 post-rainy season. Variations in mycoflora of different soils may also account for differential populations of $A$. flavus in these soils. $M$. phaseolina and $A$. niger appeared to be dominant in Vertisols where they may compete with or be antagonistic to $A$. flavus. $A$. flavus has an important competitive advantage in times of drought stress when the activity of many other soil fungi is at a minimum. This ability of survival at low moisture availability, and favorable soil aeration may be responsible for the dominance of $A$. flavus in Alfisols.
Genotypic differences for $A$. flavus infection and aflatoxin contamination of seed were conspicuous in all trials across locations. These results provide additional confirmation of the resistance to $A$. flavus infection of seeds in certain groundnut genotypes (Mehan et al., 1987) and of the stability of this resistance.

The moderate to severe preharvest droughts and favorable postharvest drying conditions in the trials suggest that most of the seed infection by $A$. flavus in the test genotypes originated before harvest.

The results of the present investigations clearly indicate lower risk of preharvest $A$. flavus infec- 
tion and aflatoxin contamination in groundnuts grown in Vertisols than in Alfisols.

It will be useful to assess preharvest aflatoxin contamination risks in black soils (Vertisols) in different agroecological zones in various groundnut-growing countries of the SAT where considerable production is on such soils (Virmani and Singh, 1986). The results will be of value in making surveys of aflatoxin contamination of groundnuts in Vertisols to assess risks, as it will help identify areas with low- or no aflatoxin risk.

It would be interesting to assess the aflatoxin risks in such soil types varying in $\mathrm{pH}$ (from acidic to alkaline). It would also be useful to examine the effects of different moisture levels on soil populations of the A. flavus group fungi in Vertisols.

\section{Acknowledgements}

The authors are grateful to Mr V R Prabhakar, Statistics Unit, ICRISAT, for providing advice and assistance in the statistical analysis.

\section{References}

Blaney B J 1985 Mycotoxins in crops grown in different climatic regions of Queensland. In Trichothecenes and Other Mycotoxins. Ed. J Lacey. pp 97-108. Wiley, Chichester, UK.

Davidson J I, Hill R A, Cole R J, Mixon A C and Henning R J 1983 Field performance of two peanut cultivars relative to aflatoxin contamination. Peanut Sci. 10, 43-47.

Dickens J W 1977 Aflatoxin occurrence and control during growth, harvest and storage of peanuts. In Mycotoxins in
Human and Animal Health. Eds. J V Rodricks, C W Hesseltine and M Mehlman. pp 99-105. Pathotox Publishers, Inc., IL.

Graham J C 1982 Preharvest aflatoxin contamination in Queensland peanuts. Queensland Department of Primary Industries Bulletin QB82001, Brisbane, Australia. 37 p.

Griffin G J and Garren K H 1976 Colonization of rye green manure and peanut fruit debris by Aspergillus flavus and Aspergillus niger group in field soils. Appl. Environ. Microbiol. 32, 28-32.

Manzo S K and Misari S M 1989 Status and management of aflatoxin in groundnuts in Nigeria. In Aflatoxin Contamination of Groundnut: Proceedings of the International Workshop. Eds. D McDonald and V K Mehan. pp 77-90. 6-9 Oct 1987, ICRISAT Center, India. Patancheru, A.P. 502324 , India.

Mehan V K, McDonald D and Rajagopalan K 1987 Resistance of peanut genotypes to seed infection by Aspergillus flavus in field trials in India. Peanut Sci. 14, 17-21.

Mehan V K, McDonald D, Ramakrishna N and Williams J H 1986 Effects of genotype and date of harvest on infection of peanut seed by Aspergillus flavus and subsequent contamination with aflatoxin. Peanut Sci. 13, 46-50.

Pettit R E, Taber R A, Schroeder H W and Harrison A L 1971 Influence of fungicides and irrigation practice on aflatoxin in peanuts before digging. Appl. Microbiol. 22, $629-634$

Pons W A, Cucullu A F, Lee L S, Franz A O and Goldblatt L A 1966 Determination of aflatoxins in agricultural products: Use of aqueous acetone for extraction. J. Assoc. Off. Anal. Chem. 49, 554-562.

Sanders T H, Cole R J, Blankenship P D and Hill R A 1985 Relation of environmental stress duration to Aspergillus flavus invasion and aflatoxin production in preharvest peanuts. Peanut Sci. 12, 90-93.

Sanders T H, Hill R A, Cole R J and Blankenship P D 1981 Effect of drought on occurrence of Aspergillus flavus in maturing peanuts. J. Am. Oil. Chem. Soc. 58, 966A970A.

Virmani S M and Singh P 1986 Agroclimatological characteristics of the groundnut-growing regions in the semi-arid tropics. In Agrometeorology of Groundnut. Eds. M V K Sivakumar and S M Virmani. pp 35-45. 21-26 Aug 1985, ICRISAT Sahelian Center, Niamey, Niger. 